Geosistemy perehodnykh zon = Geosystems of Transition Zones / Геосистемы переходных зон

Content is available under the Creative Commons Attribution 4.0 International License (CC BY 4.0)

2021, том 5, № 2, с. 179-188

URL: http://journal.imgg.ru/archive.html ; https://elibrary.ru/title about.asp?id=64191

https://doi.org/10.30730/gtrz.2021.5.2.179-188

\title{
Estimation of the runoff elasticity of the rivers \\ in the eastern part of the Amur River basin
}

\author{
Sergey Yu. Lupakov, https://orcid.org/0000-0002-5804-2604, rbir@mail.ru \\ Pacific Geographical Institute FEB RAS, Vladivostok, Russia
}

Abstract PDF ENG Резюме PDF RUS $\quad$ Full text PDFRUS

Abstract. Taking into account the unstable moisture regime and the diversity of landscapes within the Amur River basin, the problem of assessing the impact of climatic changes on the processes of surface water cycle in the region becomes multifaceted, associated with the solution of particular problems. This work studied the reaction of a river runoff to changes in the amount of atmospheric precipitation on the basis of the elasticity coefficient. Small and medium-sized river basins (52 in total) belonging to the system of the Middle and Lower Amur are the objects of this study. The data of standard observations at hydrological posts and meteorological points for the summer-autumn flood hazard period (June-September) were used. The data series were selected to include different moisture conditions. It was found that with an increase in precipitation by $1 \%$, the river runoff in the flood hazard season has increased by $1.02-3.86 \%$ in 48 cases, and decreased in 4 cases. The results of the work are fundamentally close to the regional estimates within the basin of the Amur River on the base of the analysis of factual material (including the near abroad) and simulation results, as well as to the values of the runoff elasticity coefficient obtained in different geographic zones and given in the specialized literature. The relationship between the elasticity coefficient values of runoff with various basin indicators has been studied. For the rivers in the Primorsky Kray (catchment area of the Ussuri River), the relationship between the elasticity coefficient values and the seasonal runoff and precipitation, the runoff coefficient, average height, catchments slopes and average river network slopes has been revealed. The influence of local conditions of runoff formation on the river basins response to changes in the amount of atmospheric precipitation is discussed.

Keywords:

elasticity coefficient, precipitation, streamflow, climate changes, Amur river

For citation: Lupakov S.Yu. Estimation of the runoff elasticity of the rivers in the eastern part of the Amur River basin. Geosistemy perehodnykh zon = Geosystems of Transition Zones, 2021, vol. 5, no. 2, pp. 179-188. (In Russ., abstr. in Engl.). https://doi.org/10.30730/gtrz.2021.5.2.179-188

Для цитирования: Лупаков С.Ю. Оценка эластичности стока рек восточной части бассейна Амура. Геосистемы переходных зон, 2021, т. 5, № 2, с. 179-188. https://doi.org/10.30730/gtrz.2021.5.2.179-188

\section{References}

1. Bugaets A.N., Pshenichnikova N.F., Tereshkina A.A., Krasnopeev S.M., Gartsman B.I. 2015. Analysis of the spatial differentiation of the soil cover in the south of the Far East of Russia by the example of the Komarovka River basin. Eurasian Soil Science, 48(3): 231-239. https://doi.org/10.1134/s1064229315030023

2. Gartsman B.I. 2008. [Rain floods on rivers: methods of calculation, forecasts, risk assessments]. Vladivostok: Dalnauka, 223 p. (In Russ.)

3. Gartsman B.I. 2014. Hydrographic and landscape description of a river basin based on GIS- and geographic data. Russian Meteorology and Hydrology, 39(6): 407-415. https://doi.org/10.3103/S1068373914060077

4. Gartsman B.I., Galanin A.A. 2011. Structural-hydrographic and morphometric analysis of river systems: Theoretical aspects. Geography and Natural Resources, 32(3): 226-234. https://doi.org/10.1134/s1875372811030048

5. Gartsman B.I., Lupakov S.Y. 2017. Effect of climate changes on the maximal runoff in the Amur basin: estimation based on dynamic-stochastic simulation. Water Resources, 44(5): 697-706. https://doi.org/10.1134/S0097807817050062

6. Gartsman B.I., Lupakov S.Y. 2019. Assessment of the Ussuri river flood regime changes regarding to climate projections to the end of the XXI century. Gidrosfera. Opasnye protsessy i yavleniya [Hydrosphere. Hazard processes and phenomena], 1(1): 51-69. (In Russ.). https://doi.org/10.34753/HS.2019.1.1.006

7. Gelfan A.N., Kalugin A.S., Motovilov Y.G. 2018. Assessing Amur water regime variations in the XXI century with two methods used to specify climate projections in river runoff formation model. Water Resources, 45(3): $307-317$. https://doi.org/10.1134/S0097807818030065

8. Meshchenina L.A., Novorotsky P.V., Ponomarev V.I. 2007. Climatic changes and fluctuations of the Amur runoff. Vestnik DVO RAN = Vestnik of the Far East Branch of the Russian Academy of Sciences, 4: 44-54. (In Russ.).

9. Mordovin A.M. 1996. [Annual and seasonal river flow of Amur basin]. Khabarovsk: Inst. of Water and Ecology Problems, Khabarovsk Research Center, FEB RAS, 72 p. (In Russ.)

10. Novorotskii P.V. 2007. Climate changes in the Amur river basin in the last 115 years. Russian Meteorology and Hydrology, 32(2): 102-109. https://doi.org/10.3103/S1068373907020045 
11. Novorotsky P.V. 2011. Recent climatic changes in the basin of Amur river and on the shore of Sea of Japan. Izvestiya Russkogo geograficheskogo obshchestva, 143(1): 41-48. (In Russ.).

12. Novorotsky P.V. 2013. Long term changes of air temperature in the Bureya river basin. Geography and Natural Resources, 2: 118-124. (In Russ.).

13. Khon V.C., Mokhov I.I. 2012. The hydrological regime of large river basins in Northern Eurasia in the XX-XXI centuries. Water Resources, 39(1): 1-10. https://doi.org/10.1134/S0097807812010058

14. Barrera C., Cobo J., Souvignet M., J., Oyarzun J., Oyarzun R. 2020. Streamflow elasticity, in a context of climate change, in arid Andean watersheds of north-central Chile. Hydrological Sciences Journal, 65: 1707-1719. https://doi.org/10.1080/02626667.2020.1770764

15. Chiew F. 2006. Estimation of rainfall elasticity of streamflow in Australia. Hydrological Sciences Journal, 51(4): $613-625$. https://doi.org/10.1623/hysj.51.4.613

16. Chiew F., Peel M.C., McMahon T., Siriwardena L. 2006. Precipitation elasticity of streamflow in catchments across the world. In: Climate Variability and Change: Hydrological Impacts. Wallingford, UK: IAHS Press, 256-262.

17. Chiew F., Potter N.J., Vaze J., Petheram C., Zhang L., Teng J., Post D.A. 2013. Observed hydrologic non-stationarity in far south-eastern Australia: implications for modelling and prediction. Stoch. Env. Res. Risk A., 28: 3-15. https://doi.org/10.1007/s00477-013-0755-5

18. IPCC: Climate Change 2013 - The Physical Science Basis - Contribution of Working Group I to the Fifth Assessment Report of the Intergovernmental Panel on Climate Change. 2013. Cambridge: Cambridge Univ. Press, 1535 p.

19. Kim B.S., Hong S.J., Lee H.D. 2013. The potential effects of climate change on streamflow in rivers basin of Korea using rainfall elasticity. Environmental Engineering Research, 18(1): 9-20. https://doi.org/10.4491/eer.2013.18.1.009

20. Krysanova V., Hattermann F.F. 2017. Intercomparison of climate change impacts in 12 large river basins: overview of methods and summary of results. Climatic Change, 141: 363-379. https://doi.org/10.1007/s10584-017-1919-y

21. Sankarasubramanian A., Vogel R. 2003. Hydroclimatology of the continental United States. Geophysical Research Letters, 30(7). p. 1363. https://doi.org/10.1029/2002GL015937

22. Sankarasubramanian A., Vogel R., Limbrunner J. 2001. Climate elasticity of streamflow in the United States. Water Resources Research, 37(6): 1771-1781. https://doi.org/10.1029/2000WR900330

23. Seymenov K. 2020. Climate elasticity of annual streamflow in Northwest Bulgaria. In: S. Nedkov et al. (eds). Smart Geography. Key Challenges in Geography (EUROGEO Book Series). Cham: Springer Intern. Publ., 105-115.

24. Yang H., Yang D. 2011. Derivation of climate elasticity of runoff to assess the effects of climate change on annual runoff. Water Resources Research, 47(7): W07526. https://doi.org/10.1029/2010WR009287

25. Zhou X., Zhang Y., Yang Y. 2015. Comparison of two approaches for estimating precipitation elasticity of streamflow in China's main river basins. Advances in Meteorology, 2015: 1-8. https://doi.org/10.1155/2015/924572 